\title{
Scavenging activity, anti-inflammatory and diabetes related enzyme inhibition properties of leaves extract from some varieties of Phoenyx dactylifera I.
}

\author{
Laouini S. Eddine ${ }^{1,2, \star}$, Ladjel Segni ${ }^{3}$, Gherraf Noureddine ${ }^{4}$, \\ Ouahrani Mohammed Redha ${ }^{3}$, Mokni Sonia ${ }^{5}$ \\ ${ }^{1}$ Department of Industrial Chemistry, Mohammed Kheider University, Biskra, Algeria \\ ${ }^{2}$ Laboratory of Valorisation and Technology of Saharian Resources, El-Oued University, Algeria \\ ${ }^{3}$ Process Engineering Laboratory, Kasdi Merbah University, Ouargla, Algeria \\ ${ }^{4}$ Laboratory of Biomolecules and Plant Breeding, Larbi Ben M'hidi University, Algeria \\ ${ }^{5}$ Laboratory of Wastewater Treatment, Water Researches and Technologies, Tunisia \\ *E-mail address: Salah_laouini@yahoo.fr
}

\begin{abstract}
In this study we investigate the antioxidant, anti-inflammatory, and antidiabetic activities of ethanolic leaves extracts of three selected varieties of Phoenyx dactylifera L. namely: "Ghars", "Deglet Nour" and "Hamraya". The assessment of the antioxidant potential of crude leaves extracts, using superoxide anions inhibition, DPPH and total antioxidant activity essays, was carried out. Furthermore, the anti-inflammatory properties of the extracts were determined by measuring the inhibition of nitric oxide (NO) production. Moreover, the antidiabetic effect was evaluated by inhibition of $\alpha$-amylase enzymes. The total phenolic content measured by Folin-ciocalteu method was as well conducted. The raw leaves extracts of the selected varieties was found to contain a high content of total phenolic content (342.45 mg GAE/gDW for GE) and therefore exhibited a higher antioxidant activity and inhibitory effect of radicals scavenging activity against $\mathrm{DPPH}$ and superoxide anion $\left(\mathrm{IC}_{50}=7.44 \mu \mathrm{g} / \mathrm{mL}\right.$ and $39.11 \mu \mathrm{g} / \mathrm{mL}$ respectively). The three varieties exhibited significant inhibition nitric oxide using in-vitro assay $\left(\mathrm{IC}_{50}=240.28 \mu \mathrm{g} / \mathrm{mL}\right.$ for GE). The extracts also displayed high inhibition actions against $\alpha$-amylase enzymes. The results suggest that the leaves of the three selected varieties of Phoenyx dactylifera can be considered as a good source of natural antioxidant and anti-inflammation drugs as well as potent antidiabetic medicine.
\end{abstract}

Keywords: Phoenyx dactylifera L; phenolic content; leaves extract; Scavenger activity; antiinflammatory; antidiabetic
Abbreviation
GE: Ghars extract
DNE: Deglet Nour Extract
HE: Hamraya extract 


\section{INTRODUCTION}

Phoenyx dactylifera L (Synonyms Palma major Garsault and Phonyx cycadifolia Hort. Attens ex Regel) from the family Arecaceae, is an Arecales species widely distributed in North Africa and Southeast Asia [1-3]. Phoenyx dactylifera L. is an evergreen tree and can grow in high region (altitude of $1500 \mathrm{~m}$ ) of course in well-drained soils [4-5]. This tree involves many varieties, depending on the shape and the organoleptic properties of the fruits. It is estimated that there are more than 600 varieties of this species worldwide [6]. The harvesting period of the fruits is spread out over dry-months from July to October. The plantderived medicines are based upon the promise that they contain natural compounds that can promote health and alleviate harm.

These species are considered as important source of biologically active compounds whose effect on human health or genetic martial is mostly unknown [7-8]. Some varieties involve different phytochemicals and enzyme that act as antioxidant agents to maintain growth and metabolism [9-10]. Polyphenols are secondary metabolites biosynthesized by plant against pathogen attack and UV stress [11-12]. These compounds including flavonoids, phenolic acids and tannins are groups of phytochemicals that exhibited strong antioxidant action and a considerable free radical scavenging effect by their reactivity as hydrogen-or electro-donating agent $[13,14]$.

Natural antioxidants such as phenolic compounds are associated with a reduced risk of chronic inflammation, cancer and cardiovascular diseases [15-17] and could protect membrane lipid from oxidation [18]. In the food industry, synthetic antioxidants are often used because they are effective and less expensive than natural antioxidants. However, many researchers have reported adverse effects of synthetic antioxidants due to their toxicity and carcinogenicity [19] and because they were found to exhibit mutagenesis and liver damage in both human and animals [20]. The growing interest in the substitution of synthetic food antioxidants by natural ones has fostered research on the screening of plants extract for identifying new antioxidants.

The objective of the present study was to evaluate the antioxidant, anti-inflammatory and antidiabetic effects of ethanolic leaves extract of three varieties of Phoenyx dactylifera $L$,

\section{EXPERIMENTAL}

\section{1. Plant material and extraction}

The leaves of the three varieties of Phoenyx dactylifera L. were collected from southeast of Algeria, state of El Oued (Debila district) on November 2011. Botanical identification was carried out by Pr. Ouahrani $\mathrm{M}^{\text {ed }}$ Redha, Department of chemistry; university of Ouargla; Algeria. The leaves of five varieties were thoroughly washed and reduced into small pieces before being ground and powdered into particles (about $1 \mathrm{~mm}$ in size). Then the powder was put in a hot air oven at $60^{\circ} \mathrm{C}$ until complete drying. Depending on the physical characteristics of the samples, the time ranged from 18 at $30 \mathrm{~h}$.

The bioactive compounds were extracted according to the method described by Bebbar et al [21] and Delgado et al [22]. $100 \mathrm{~g}$ of the leaves of each variety were extracted with 400 $\mathrm{mL}$ of $70 \% \mathrm{v} / \mathrm{v}$ of ethanol-water for $5 \mathrm{~h}$ in Soxhlet. The extracts were filtered and evaporated under vacuum at $45{ }^{\circ} \mathrm{C}$ before being dried and lyophilized for $10 \mathrm{~h}$. the raw extract was stored at $-40{ }^{\circ} \mathrm{C}$. 


\section{2. Determination of total phenolic content}

The total phenolic contents in the selected varieties were determined by the folinCiocalteu method developed by Singleton and Rossi [23] with some modifications [24]. Briefly, $100 \mu \mathrm{L}$ of both the sample and the standard (gallic acid) of known concentrations were made up to $2.5 \mathrm{~mL}$ with water and mixed with $0.25 \mathrm{~mL}$ of $1 \mathrm{~N}$ Folin-ciocalteu reagent. After $5 \mathrm{~min}, 2.5 \mathrm{~mL}$ of sodium carbonate aqueous solution $(2 \%, \mathrm{w} / \mathrm{v})$ was added to the mixture and was completed the reaction for $120 \mathrm{mn}$ in darkness at room temperature. The absorbance was read at $765 \mathrm{~nm}$ using a UV-visible spectrophotometer. For the blank the same protocol was used but the extract was replaced by ethanol (70\%). The results were expressed in equivalent milligrams of gallic acid per gram of dry weight of plant extract (mg GAE/gDW). The experiment was conducted in triplicate and the results were expressed as means \pm SD (standard deviation) value.

\section{3. DPPH radical scavenging activity}

The radical scavenging activity using free-radical DPPH assay was carried out using the method described by Hatano et al [25] and Falleh et al [26]. $1 \mathrm{~mL}$ aliquot of each extract was added to $0.5 \mathrm{~mL}$ of a DPPH ethanolic solution ( $7.8 \mathrm{mg}$ DPPH in $100 \mathrm{~mL}$ ethanol $70 \%$ ). The mixture was vigorously shaken and left to stand in the dark for $30 \mathrm{~min}$ at room temperature. The antioxidant activity was then measured by the decrease in absorption at $517 \mathrm{~nm}$ using UV-Visible spectrophotometer and corresponds to the extract ability to reduce the radical DPPH to the yellow-colored diphenilpicryldrazine. The antiradical activity was expressed as $\mathrm{IC}_{50}(\mu \mathrm{L} / \mathrm{mL})$ i.e. the antiradical percentage inhibition calculated by the following equation:

$$
\text { DPPH scavenging activity }=\left[\left(\begin{array}{ll}
A_{o} & A_{1}
\end{array}\right) / A_{o}\right] \times 100
$$

where $A_{o}$ is the absorbance of control test after $30 \mathrm{~min} . A_{1}$ is the absorbance of the sample extract after $30 \mathrm{~min}$. All results are means $( \pm \mathrm{SEM})$ and were performed in triplicate.

\section{4. Scavenging activity of superoxide radicals}

The superoxide anion scavenging of extracts was estimated using the inhibition of NBT reduction by photochemical generated $\mathrm{O}_{2}{ }^{-}$. To the assay mixture contained $2 \mu \mathrm{M}$ of riboflavin, we added $6 \mu \mathrm{M}$ EDTA, $50 \mu \mathrm{M}$ NBT and $3 \mu \mathrm{g}$ of sodium cyanide in $67 \mathrm{mM}$ phosphate buffer $(\mathrm{pH}=7.8)$ in a final volume of $3 \mathrm{~mL}$. Initial absorbance was measured at $530 \mathrm{~nm}$, the tubes were illuminated uniformly with incandescent lamp at $530 \mathrm{~nm}$. The sample extract was added to the reaction mixture, in which $\mathrm{O}_{2}^{-}$radicals are scavenged, thereby inhibition the NBT reduction [27-28]. Quercetin used as a positive control and the percentage of scavenging inhibition was calculated as:

$$
\% \text { inhibition }=\left[\left(\mathrm{A}_{\text {control }}-\mathrm{A}_{\text {sample }}\right) / \mathrm{A}_{\text {control }}\right] \times 100
$$

$\mathrm{IC}_{50}$ value is the concentration $(\mu \mathrm{g} / \mathrm{mL})$ of the tested material that causes $50 \%$ loss of superoxide radicals calculated by the linear regression analysis.

\section{5. Nitric oxide generation and determination by Griess reagent}

Nitric oxide was produced from sodium nitroprusside. It interacts with oxygen to produce nitrite ion and determined by the use of Griess reagent [29-31]. A volume of $2 \mathrm{~mL}$ of 
sodium nitroprusside prepared in saline phosphate buffer $(\mathrm{pH}=7.4)$ was added to $0.5 \mathrm{~mL}$ of different concentrations of plant extracts, BHT and querecetin. The mixture was set at $25{ }^{\circ} \mathrm{C}$ for $150 \mathrm{~min}$. $0.5 \mathrm{~mL}$ of each sample from above solutions were added to $0.5 \mathrm{~mL}$ of Griess reagent ( $1 \%$ sulphanilamide, $2 \% \mathrm{H}_{3} \mathrm{PO}_{4}$ and $0.1 \%$ ACS reagent) and allowed to stand for 30 min. The absorbance of the chromophore formed during the diazotization of nitrite with sulphanilamide and subsequent coupling with naphtylethylene diamine was measured at 546 $\mathrm{nm}$. The amount of nitric oxide radicals was calculated using the equation 2 .

\section{6. Antidiabetic activity against Alpha-amylase}

The antidiabetic activity of leaves extracts of Pheonyx dactylifera L . against $\alpha$-amylase was performed by the method described by Kunyanaga et al [32]. A volume of $100 \mu \mathrm{L}$ of sodium phosphate buffer at concentration $0.02 \mathrm{~mol} / \mathrm{L}(\mathrm{pH}=6.9)$ was mixed with $100 \mu \mathrm{L}$ of ethanolic the extract (various concentrations) and was added to $100 \mu \mathrm{L}$ of $\alpha$-amylase enzyme ( $1 \mathrm{~mL}$ liberates $1.9 \mu \mathrm{g}$ of maltose). The resulting mixture was added to $100 \mu \mathrm{L}$ of starch-water $(1 \mathrm{~g} / 100 \mathrm{~mL})$ and incubated at $25{ }^{\circ} \mathrm{C}$ for $30 \mathrm{~min}$. the reaction was stopped with $1 \mathrm{~mL}$ of dinitrosalicylic acid reagent. The mixtures were incubated in a boiling water bath for $5 \mathrm{~min}$ and allowed to stand and cool at room temperature before the addition of $5.4 \mathrm{~mL}$ of distilled water. The absorbance of reaction mixture at $540 \mathrm{~nm}$ was measured and compared with the control (buffer solution without extract) using UV-Visible . The percentage inhibition of $\alpha$ amylase by the ethanolic extract was calculated using the equation 2 .

\section{7. Statistical analyses}

Data are expressed as means $\pm \mathrm{SD}$ (standard deviation) from three replicates. The statistical analyses were performed with ANOVA test, taking a probability of $0.05 \%$ as the criterion of significance $(\mathrm{P}<0.05)$.

\section{RESULTS AND DISCUSSION}

Date palm fruit has important bioactive effects due to its content of various phytochemical compounds. Recently some studies that supported these results were reported $[28,33,34]$. Thus, our study was undertaken considering the leaves of three varieties. To the best of our knowledge, the leaves extracts have not been investigated so far.

\section{1. Extraction yields and phenolic contents}

The yields of ethanolic leaves extract of selected varieties of Phoenyx dactylifera L. were measured. Ethanol is considered as a selective solvent to extract a wide range of bioactive molecules with high yield [35]. The output of Ghars variety (GE) was significantly greater than that of the other varieties $(18.43 \pm 0.8 \%)$. The output for the Deglet Nour (DNE) and Hamraya varieties (HE) were $17.15 \pm 0.5 \%$ and $16.20 \pm 0.54$ respectively.

The total phenolic content of the ethanolic extracts is given in Figure 1. The values vary from $180.27 \pm 7.25$ to $342.45 \pm 12.5 \mathrm{mg} \mathrm{GAE} / \mathrm{g} \mathrm{DW}$. Ghars variety was found to have the highest value of phenolic content (342.45 $\pm 12.5 \mathrm{mg}$ GAE/g DW). Deglet Nour and Hamraya were considered as rich in phenolic compounds with a concentration of $221.75 \pm 9.59$ and $190.27 \pm 6.55 \mathrm{mg} \mathrm{GAE} / \mathrm{g}$ DW respectively. 


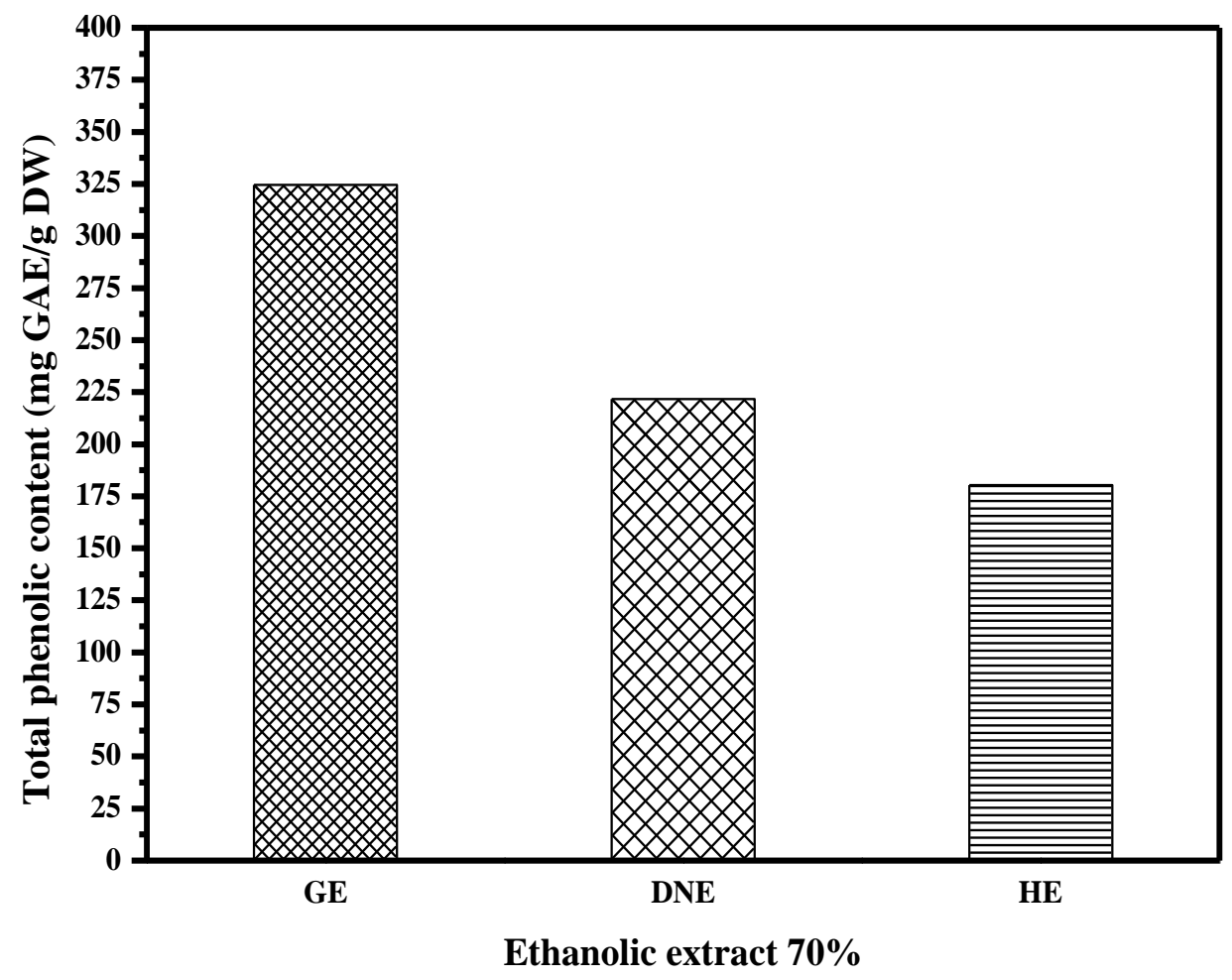

Fig. 1. Total phenolic contents of selected varieties of Phoenyx dactylifera expressed as mg GAE/g DW. Results are expressed as the mean \pm standard deviation $(n=3)$.

\section{2. DPPH radical scavenging inhibition}

The DPPH radical scavenging activity of ethanolic leaves extract of the three varieties of Phoenyx dactylifera is represented in Figure 2. The crude extract of Ghars variety displayed the highest value $\left(\mathrm{IC}_{50}=7.44 \pm 0.08 \mu \mathrm{g} / \mathrm{mL}\right)$. Deglet Nour exhibited an intermediate value: $\left(\mathrm{IC}_{50}=10.25 \pm 0.09 \mu \mathrm{g} / \mathrm{mL}\right.$ ).

The lowest amount was observed in Hamraya variety $\left(\mathrm{IC}_{50}=12.61 \pm 0.08 \mu \mathrm{g} / \mathrm{mL}\right)$. The antioxidant capacity of different varieties of Phoenyx dactylifera is higher than the positive control BHT $\left(\mathrm{IC}_{50}=14.46 \pm 0.06 \mu \mathrm{g} / \mathrm{mL}\right)$.

\section{3. Scavenging of superoxide radicals activity}

The assay was based on the capacity of different extracts of Phoenyx dactylifera L. to enhance the formation of formazane in comparison to the NBT/riboflavin reference signal [27]. The results of selected varieties are represented in Figure 3. The scavenging activity of GE exhibited higher inhibition $\left(\mathrm{IC}_{50}=39.11 \pm 0.92 \mu \mathrm{g} / \mathrm{mL}\right)$ and $67.32 \pm 1.7 \mu \mathrm{g} / \mathrm{mL}$ for DNE, while leaves extract of $\mathrm{HE}$ variety displays the lowest response in this assay $\left(\mathrm{IC}_{50}=89.73\right.$ $\pm 2.12 \mu \mathrm{g} / \mathrm{mL})$.

These extracts exhibited more activity than the querecetin $\left(\mathrm{IC}_{50}=327.95 \pm 12.25\right.$ $\mu \mathrm{g} / \mathrm{mL}$ ). Data are collected in Figure 3 . 


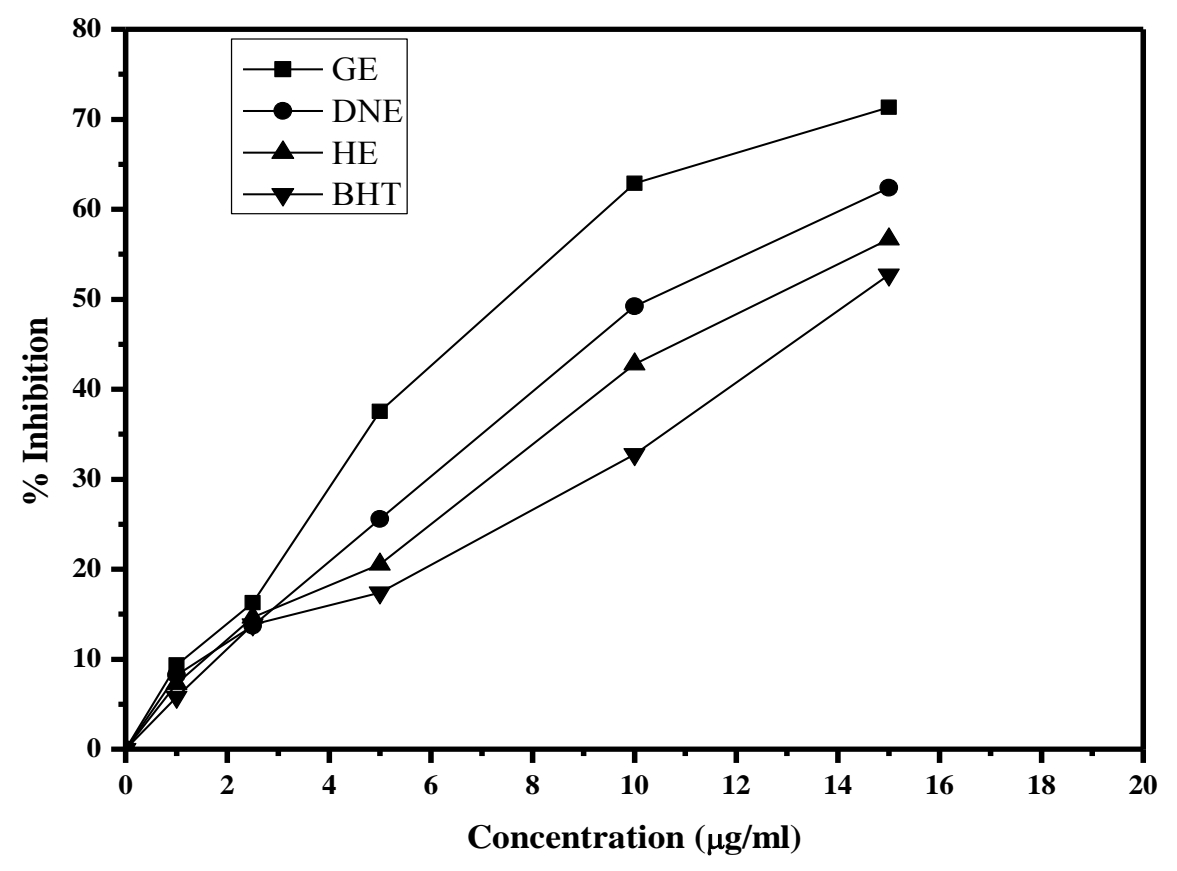

Fig. 2. DPPH radical activity of ethanolic extract of selected varieties from Phoenyx dactylifera $\mathrm{L}$ and standards BHT. Values are mean \pm SD of three separate experiments done in triplicate.

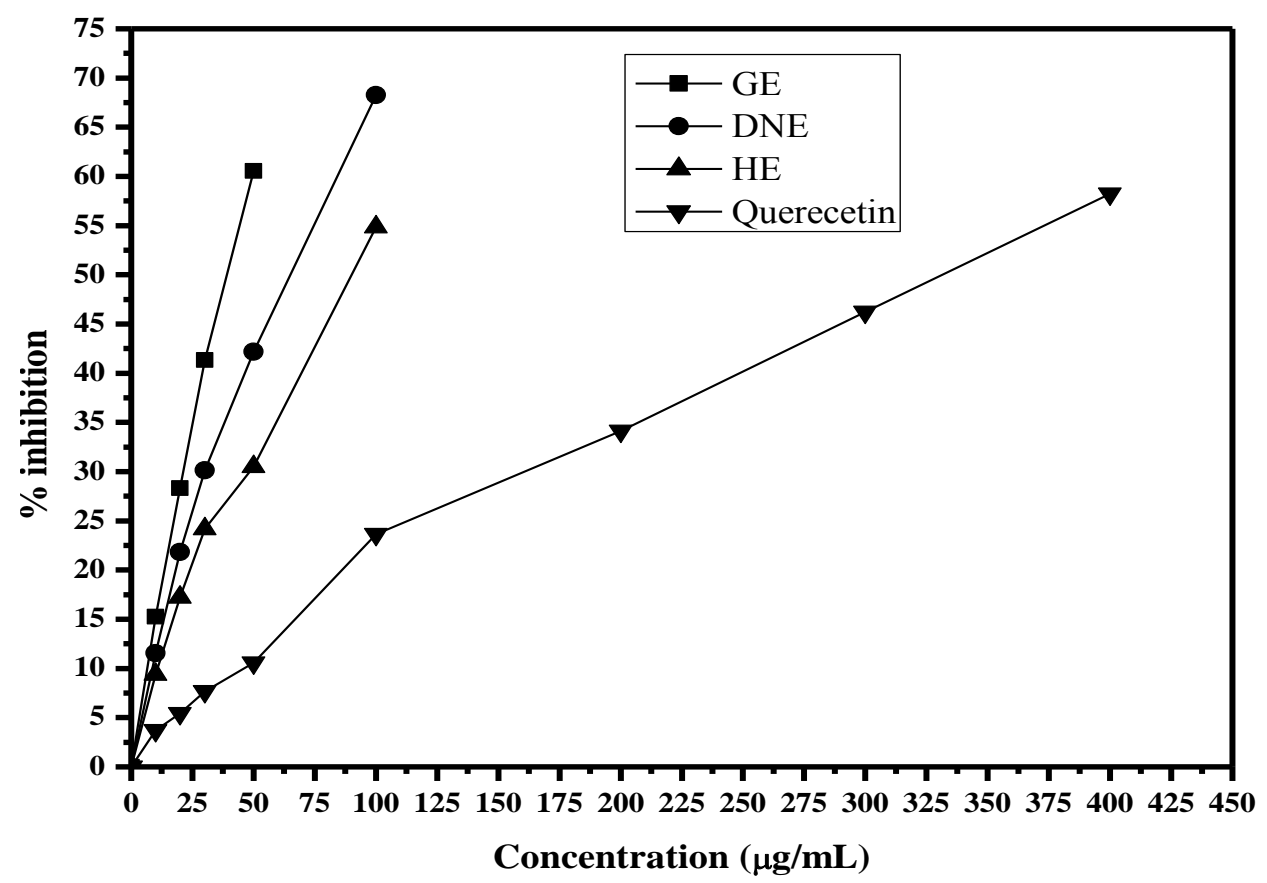

Fig. 3. Superoxide scavenging potential of ethanolic extract of selected varieties Phoenyx Dactylifera $L$. Values are mean $\pm \mathrm{SD}$ of three separate experiments done in triplicate. 


\section{4. Nitric oxide generation}

The scavenging activity of the extracts against nitric oxide was calculated. All extracts down-regulated NO production with $\mathrm{IC}_{50}<500 \mu \mathrm{g} / \mathrm{mL}$. The strongest effect was observed for the GE with an $\mathrm{IC}_{50}=240.28 \pm 8.42 \mu \mathrm{g} / \mathrm{mL}$. Regarding the other extracts, DNE $\mathrm{IC}_{50}=307.89$ $\pm 11.25 \mu \mathrm{g} / \mathrm{mL}$ and $\mathrm{HE} \mathrm{IC}_{50}=390.72 \pm 13.15 \mu \mathrm{g} / \mathrm{mL}$. The inhibition of the reference chemical BHT against nitric oxide radicals was $\mathrm{IC}_{50}=711.65 \pm 19.35 \mu \mathrm{g} / \mathrm{mL}$, the results were shown in Figure 4.

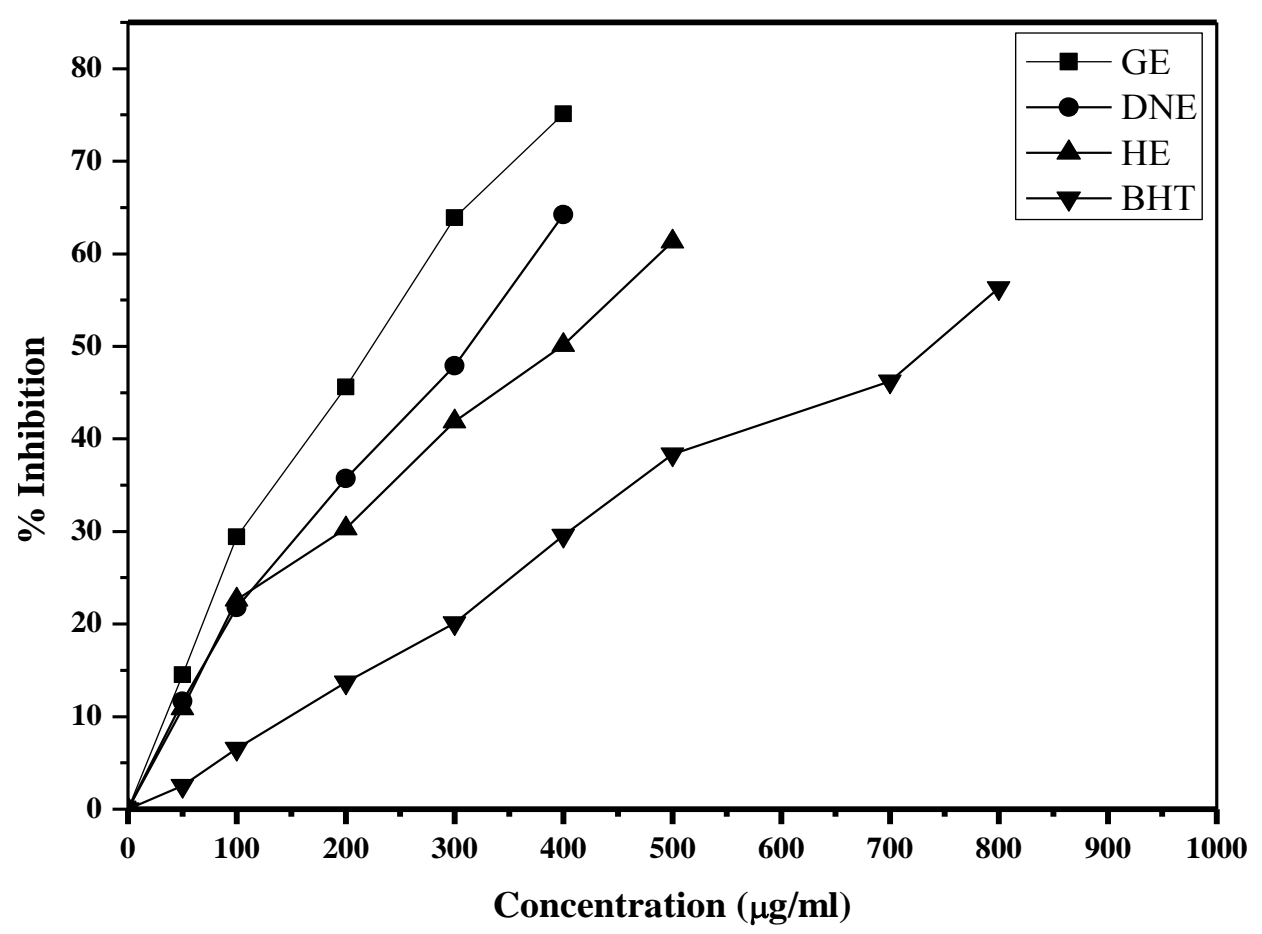

Fig. 4. Nitric oxide scavenging activities of ethanolic extract of selected varieties from Phoenyx in comparison with BHT. Results were presented as mean $\pm \mathrm{SD}(\mathrm{n}=3)$.

\section{5. $\alpha$-amylase effect}

The antidiabetic activity of the leaves extracts of selected varieties of Phoenix dactylifera $L$. against $\alpha$-amylase was investigated and the results were shown in Figure 5 . The inhibition rate of ethanolic extracts was determined by the linear regression equation. The leaves extract showed a significant inhibition of $\alpha$-amylase with the higher value obtained from the leaves extract of Ghars variety $\left(\mathrm{IC}_{50}=379.44 \mu \mathrm{g} / \mathrm{mL}\right)$. The leaves extract of Deglet Nour showed an average value $\left(\mathrm{IC}_{50}=483.74 \mu \mathrm{g} / \mathrm{mL}\right)$ and the lowest inhibition $\left(\mathrm{IC}_{50}=553.94\right.$ $\mu \mathrm{g} / \mathrm{mL}$ ) was recorded for Hamraya extract.

Phoenyx dactylifera $L$ leaves seem to be an important source of active compounds owing to their remarkable bioactive behaviour. Nevertheless, most of the literature reports deal with fruits activities [36-38]. For this reason our study was intended to investigate the leaves extracts of three varieties. To the best of our knowledge the plant leaves have not subjected to any antioxidant, anti-inflammatory or antidiabetic investigations so far. 


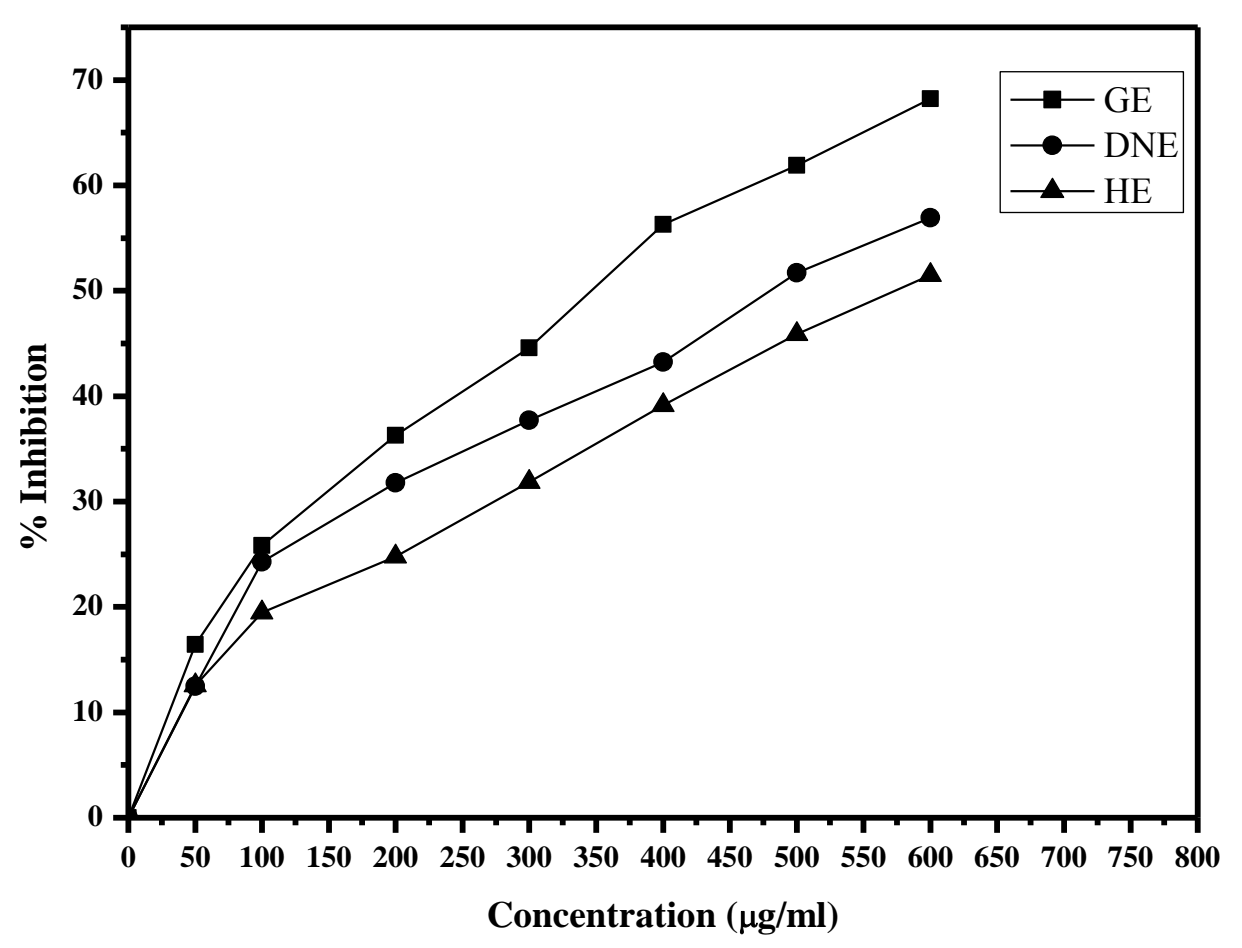

Fig. 5. $\alpha$-amylase inhibition activity (Antidiabetic activity) of ethanolic extract of selected varieties of Phoenyx dactylifera $L$.

The phytochemical analyses conducted on leaves extracts of above mentioned varieties of Phoenyx dactylifera $L$ revealed the presence of phenolic compounds, which are famous for diverse biological activities including anti-carcinogenic and anti-atherosclerotic activities related to their antioxidant capacity [39]. Phenolic compounds are also known to be used in the treatment of inflamed on ulcerated tissues and they have remarkable activity in cancer prevention, in addition to the treatment of stress-related ailment and as dressings for wounds normally encountered in circumcision rites, bruise sores [40-41]. The relatively high antioxidant capacity of leaves ethanolic extracts reflects the high level of phenolic content.

The phenolic compounds were considered to be the most active antioxidant derivatives in plants and are well known as antioxidant and scavenger agent against free radicals [42-43]. In living system, the free radicals are constantly generated and their associated with oxidative extensive damage to tissues [44-30]. Different therapeutic approaches can be used to decrease the oxidative stress including scavenging of free radicals. Inhibition of these radicals produces enzymes and enchains antioxidant system by targeting the signalling routes [45]. Many synthetic drugs protect against oxidative damage but they have adverse side effects. The present study showed that the leaves ethanolic extracts of three selected varieties of Phoenyx dactylifera $L$ have good antioxidant as well as free radicals scavenging properties. The leaves ethanolic extracts of selected varieties were very potent superoxide radicals' scavenger. These extracts were more active than the positive control (Querecetin). It seems that this activity is mostly related to the presence of the phenolic compounds. 
Superoxide radicals are generated by numerous biological and phytochemical reactions. The results suggest that concentration depends on the increasing of superoxide radical scavenging activity [27].

Numerous plants rich on phenolic compounds have been investigated as potential inhibitors of NO production in inflammatory reaction [31]. These compounds used in the treatment of chronic inflammatory diseases associated with overproduction of nitric oxide [46]. The toxicity of nitric oxide increases greatly when it reacts with superoxide radicals forming the highly reactive peroxynitrite anion $\left(\mathrm{ONOO}^{-}\right)$[47]. The nitric oxide generated from sodium nitroprusside reacts with oxygen to form nitrite. The leaves ethanolic extract of the three varieties inhibits nitrite formation by directly competing with oxygen in the reaction with nitric oxide. The present study proved that the leaves extract have good nitric oxide scavenging activity. In the other hand, these extracts show high inhibition rate against $\alpha-$ amylase enzyme. Natural sources of $\alpha$-amylase inhibitor have received a lot of interest aiming to search for alternative to synthetic enzyme inhibitors as acarbose, metformine and orlistat which have been found to exhibit adverse effect, mild efficacy and can cause gastrointestinal distress as a side effect [48].

Certain plant phenolic compounds have the ability to partially inhibit the activity of $\alpha$ amylase enzyme and they are therefore useful in dietary management of type II diabetes [4932]. Phenolics are able to bind with the reactive sites of $\alpha$-amylase and alter its catalytic effect [50], this is the first study reporting the $\alpha$-amylase inhibition activity of ethanolic leaves extracts of Ghars, Deglet Nour and Hamraya variety of Phoenyx dactylifera L.

\section{CONCLUSION}

In conclusion the present study demonstrates that leaves extract of three varieties of Phoenyx dactylifera L (Ghars, Deglet Nour, Hamraya) possess potent antioxidant, antiinflammation and antidiabetic activities which comparable with the references synthetic antioxidant and anti-inflammation, and can be replaced these synthetic compounds. Further studies are in progress in this laboratory for the isolation and identification of the bioactive components.

\section{References}

[1] Al Farsi M. A, Lee C. Y., Crit. Rev. Food Sci 48 (2008) 877-887.

[2] Dowson V. H. W., FAO Food and Agriculture Organisation of the United Nations. Paper No 35. Rome (1982).

[3] Baliga M. S., Vitttaldas Baliga B. R., Kandathil S. M, Bhat H. P., Vayalil P. K., Food Res. Int. 44 (2011) 1812-1822.

[4] Al-Shahib W., Marshall R. J., Int. J. Food .Sci. Nutr. 54 (2003) 247-259.

[5] Chandra M., Riley M. G., Johnson D. E., Arch. Toxicol. 66 (1992) 496-502.

[6] Ahmed A. I., Ahmed A. W. K., Robinson R. K., Food Chem. 45 (1995) 305-309.

[7] Thomas M., Emilie D., Gaëtan Le. F., Marie E. L., Claire E., Food Chem. 131 (2012) 754-760. 
[8] Rubem C. H., Vera Maria F. V., Mutag 18 (2003) 113-118.

[9] Hossain M. A., Rahman S. M. M., Food Res. Int. 44 (2011) 672-676.

[10] Pandhair V., Sekhon B. S., J. Plant Biochem. Biotechnol. 15 (2006) 71-78.

[11] Mayer R., Stecher G., Wuerzner R., Silva R. C., Sultana T., Trojer L., et al, J. Agri. Food Chem. 56 (2008) 6959-6966.

[12] Saleem M., Nazir M., Ali M. S., Hussain H., Lee Y. S., Riaz N., et al, Nat Prod Rep 27 (2012) 238-254.

[13] Pietta P. G., J. Nat. Prod. 63 (2000) 1035-1042.

[14] Rice-Evans C. A., Miller N. J., Pacanga G., Trens plant Sc.i 2 (1997) 152-159.

[15] Edziri H., Ammar S., Souad L., Mahjoub M. A., Mastouri M., Aouni M., et al, S. Afr. J. Bot. 78 (2012) 252-256.

[16] Maria A., Harris P., Dimitris K., Alexio-Leandros S., Serkos A. H., Food Sci. Technol. Int. 48 (2012) 316-322.

[17] Proestos C., Sereli D., Komaitis M., Food Chem. 95 (2006) 44-52.

[18] Terao K., Ohmori S., Igarashi K., Ohtani I., Watanabe M. F., Harada K..I., et al, Toxicon. 32 (1994) 833-843.

[19] Sweetie R. K., Arjun K., Arun S., Food Res. Int. 44 (2011) 3182-3187.

[20] Sunday O. O., Anthony J. A., Asian Pac. J. Trop. Med. 4 (2011) 952-958.

[21] Neha B., Harinder S. O., Dewinder S. U., Ramabhau T. P., Food Res. Int. 44 (2011) 391-396.

[22] Jonathan D. A., Esther G. S., Esperanza V. S., David G. G., Food Control 24 (2012) 136-141.

[23] Singleton V. L., Rossi J. A. Jr., Am J Enol. Viticult 16 (1965) 144-158.

[24] Shaofang L., Jie S., Lina Y., Chushu Z., Jie B., Feng Z., et al, Food Chem. 134 (2012) 1885-1891.

[25] Hanato T., Kagawa H., Yasuhara T., Okuda T., Chem. Pharma. Bull. 36 (1988) 2090-2097.

[26] Falleh H., Ksouri R., Oueslati S., Guyot S., Magné C., Abdelly C., Food. Chem. Toxicol. 47 (2009) 2308-2313.

[27] Kilani-Jaziri S., Bhouri W., Skandrani I., Limem I., Chekir-Ghedira L., Ghedira K., South African Journal of Botany 77 (2011) 767-776

[28] Praveen K. Vayalil, J. Agric. Food Chem. 50 (2002) 610-617.

[29] Christudas S., Paul A., Chidambarm K., Savarimuthu I., Food. Chem. Toxicol. 50 (2012) 1547-1553.

[30] Mbaebie B. O., Edeoga H..O., Afolayan A. J., Asian Pac. J. Trop Biomed 2 (2012) 118-124.

[31] Qing-Feng Z., Yu-Xian G., Xinchen S., Guodong Z., Wen-Jun W., Food Chem. 133 (2012) 140-145. 
[32] Catherin N. K., Jasper K. I., Michael W. O., Hans K. B., Food Sci. Technol. 45 (2012) 269-276.

[33] Dhaouadi K., Raboudi F., Estevan K., Barrajon E., Vilanova E., Hamdaoui M., et al, J. Agric. Food Chem. 59 (2011) 402-406.

[34] Manjeshwar S. B., Bantwal Raghavendra V. B., Shaun M. K., Harshith P. B., Praveen K. V., Food Res. Int. 44 (2011) 1812-1822.

[35] Chaira N., Smaali M. I., Martinez-Tome M., Mrabet A., Murcia M. A., Ferchichi A., Int. J. Food Sci. Nutr. 60 (2009) 316-329.

[36] Tahraoui A., El-Hilaly J., Israili Z. H., Lyoussi B., J. Ethnopharmacol 110 (2007) 105-117.

[37] Doha M. A., Al-Okbi S. Y., Pol. J. Food Nutr. Sci. 13 (2004) 397-402.

[38] Loganayaki N., Siddhurajub P., Manian S., J. Ethnopharmacol 140 (2012) 230-233.

[39] Ruch R. J., Cheng S. J., Klaunig J..E., Carcinogens 10 (1989) 1003-1008.

[40] Motar M. L. R., Thomas G., Barbose Fillo J. M., J. Ethnopharmacol 95 (1985) 139-142.

[41] Olayinka A. Aiyegoro, Anthony I. Okoh, BMC Complement Altern. Med. 10(21) (2010) $1-8$.

[42] Edenharder R., Grunhage D., Mutat. Res. 540 (2003) 1-18.

[43] Park K. Y., Jung G. O., Lee K. T., Choi J., Choi M. Y., Kim G. T., et al, J. Ethnopharmacol 90 (2004) 73-79.

[44] Indrajit K., Narayan D., Pathik S., Nilanjan S., Asis B., Pallab K. H., Orient Pharm Exp. Med. 11 (2011) 221-228.

[45] Kundu S., Bala A., Ghosh P., Mukhopadhya D., Mitra A., Sarkar A., et al, Free Radic. Res. 45 (2011) 518-526.

[46] Duenas M., Hernandez T., Estrella I., Food Chem. 98 (2006) 95-103.

[47] Jiang F., Dusting G. J., Curr. Vasc. Pharmacol 1 (2003) 135-156.

[48] Randhir R., Kwon Y. I., Shetty K., Innovat Food. Sci Emerg. Tech. 9 (2008) 355-364.

[49] Chethan S., Sreerama Y. N., Malleshi N. G., Food Chem. 111 (2008) 187-191.

[50] Qi Y., Feng C., Xi W., Yueming J., Songyi L., LWT - Food Sci. Technol. 46 (2012) 164-168. 